УДК 378.012:378.014.6

DOI:

Надія Стеценко, кандидат педагогічних наук, доцент, дочент кафедри педагогіки та освітнього менеджменту, директор Центру дистаниійного навчання Уманського державного педагогічного університету імені Павла Тичини

Зоя Комарова, кандидат філологічних наук, доцент, дочент кафедри украӥнської мови та методики ї̈ навчання, директор Центру забезпечення функиіонування системи управління якістю освітньої діяльності Уманського державного педагогічного університету імені Павла Тичини

Галина Ткачук, доктор педагогічних наук, доцент, доиент кафедри інформатики та інформаціийн-комунікаційних технологій

Уманського державного педагогічного університету імені Павла Тичини

Володимир Стеценко, кандидат педагогічних наук, доцент, доцент кафедри інформатики та інформаційно-комунікаційних технологій Уманського державного педагогічного університету імені Павла Тичини

\title{
ДОСВІД ОРГАНІЗАЦІЇ ТА ПРОВЕДЕННЯ ОПИТУВАННЯ СТУДЕНТІВ ПРО ЯКІСТЬ НАДАННЯ ОСВІТНІХ ПОСЛУГ В УНІВЕРСИТЕТІ
}

У статті представлено досвід організації та проведення опитування студентів з метою оцінювання ними якості надання освітніх послуг в університеті. Авторами проаналізовано основні документи, які стосуються акредитації освітніх програм, виявлено, що вирішальним чинником у якісному наданні освітніх послуг є залучення здобувачів вищої освіти до прочесу оцінювання освітніх програм та інших процедур забезпечення якості. Досвід організачії і проведення опитування студентів описано на прикладі анкетування здобувачів освітнього рівня “Бакалавр" за всіма освітніми напрямами університету. Авторами запропоновано різні види анкетувань для студентів I - II курсів (загальне анкетування для оцінювання якості надання освітніх послуг) та III - IV курсів (анкетування для виявлення якості самостійної роботи студентів).

Ключові слова: якість освіти; освітня програма; анкетування; комп 'ютерні технології.

Puc. 3. Лim. 4.

Nadiya Stetsenko, Ph.D.(Pedagogy), Associate Professor of the Pedagogy and Educational Management Department, Uman Pavlo Tychyna State Pedagogical University Zoya Komarova, Ph.D.(Philology), Associate Professor of the Ukrainian Language and Methods of Teaching Department, Uman Pavlo Tychyna State Pedagogical University

Halyna Tkachuk, Doctor of Sciences(Pedagogy), Associate Professor of the Informatics and Information and Communication Technology Department

Uman Pavlo Tychyna State Pedagogical University

Volodymyr Stetsenko, Ph.D.(Pedagogy), Associate Professor of the Informatics and Information and Communication Technology Department

Uman Pavlo Tychyna State Pedagogical University

\section{THE EXPERIENCE OF ORGANIZATION AND CONDUCTING A QUESTIONNAIRE OF STUDENTS ABOUT QUALITY OF PROVIDING EDUCATIONAL SERVICES AT THE UNIVERSITY}

The article presents the experience of organizing and conducting a questionnaire of students about quality of providing educational services at the university. The authors analyzed the main documents related to the accreditation of educational programs and found that the decisive factor in the quality provision of educational services is the involvement of higher education applicants in the process of evaluation of educational programs and other procedures to ensure their quality. Experience of organizing and conducting student surveys is described on the example of the Bachelor of Education degree for all educational specialties of the University. Authors propose to conduct different types of questionnaires for I-II courses (general questionnaire for identifying the quality of educational services) and III-IV (questionnaire for identifying the quality of the students' independent work) courses.

This questioning was done by means of a Moodle system that uses a personalized login, that is each student was identified by the system during the questionnaire, so the passing of the test to third parties is excluded. At the

В. Стеценко, 2020 


\section{ДОСВІД ОРГАНІЗАЦЇ ТА ПРОВЕДЕННЯ ОПИТУВАННЯ СТУДЕНТІВ ПРО ЯКІСТЬ НАДАННЯ ОСВІТНІХПОСЛУГ В УНІВЕРСИТЕТІ}

same time, the questionnaire was completely anonymous because the system did not show specific participants in the results of the questionnaire, instead received an overall survey result.

The experience of interviewing higher education applicants is a positive practice in internal assessment of the quality of education. Involving computer technology in conducting surveys greatly simplifies the process of obtaining the result, since this form of surveys is convenient not only for the administration, but also for students who can answer remotely, from a mobile phone, where is Internet.

The practice of organizing such questionnaire indicates that the structural units (faculties, departments) can carry out the assessment of educational services independently and organize periodic surveys, questionnaires for students to receive feedback from participants in the educational process, in order to correct the educational programs of specialties, quality management practices and improving the quality system as a whole.

Keywords: a quality of education; an educational program; a questionnaire; a computer technology.

П остановка проблеми. Відповідно до Національної стратегії розвитку освіти в Україні [2] розбудова національної системи освіти вимагає зосередження зусиль та ресурсів на розв'язання найбільш гострих проблем, які стримують розвиток освітньої галузі, не дають можливості забезпечити нову якість освіти, адекватну розвиткові сучасного суспільства. Нині існує потреба створення гнучкої, цілеспрямованої, ефективної системи державногромадського управління освітою, яка забезпечуватиме інтенсивний розвиток та якість освіти, спрямованість їі на задоволення запитів держави та особистості зокрема.

Вирішальним чинником для створення такої системи та подолання зазначених проблем $є$ розв'язання питання якості надання освітніх послуг у закладах вищої освіти (ЗВО)

Аналіз останніх досліджень і публікацій. Проблема удосконалення якості освіти та надання освітніх послуг висвітлена у працях таких учених, як В. Андрущенко, В. Астахова, М. Головянко, С. Гришко, Т. Добко, В. Жуковський, М. Іванчук, К. Корсак, К. Малишкіна, С. Ніколаєнко, Н. Пасічник, О. Родіонов, Л. Сподін, А. Черкасов, В. Щербак та ін. Незважаючи на високий потенціал і помітний внесок згаданих учених у розвиток вітчизняної науки, досі залишається актуальним питання якості надання освітніх послуг ЗВО. Зокрема, потребують вивчення проблеми, пов'язані 3 оцінюванням якості освіти не тільки вищими керівними органами, а й безпосередніми учасниками освітнього процесу. Це важливо особливо сьогодні у зв'язку з запровадженням нових вимог до акредитації освітніх програм, за якими здійснюється підготовка "Бакалаврів" та "Магістрів".

Крім того, є актуальним вивчення питання застосування засобів інформаційно-комунікаційних технологій у процесі оцінювання якості освіти, оскільки вони дають змогу швидше та ефективніше організувати цей процес, залучаючи до роботи набагато менше як матеріальних, так і людських ресурсів [4, 202].

Мета дослідження - описати досвід організації і проведення опитування здобувачів вищої освіти Уманського державного педагогічного університету імені Павла Тичини (УДПУ) про якість надання освітніх послуг.

Результати дослідження. Національне агентство із забезпечення якості вищої освіти розробило критерії оцінювання якості освітньої програми (ОП), за якими здійснюється підготовка здобувачів вищої освіти [1]. Один із пунктів цих критеріїв, зокрема пункт 2 критерію $8[1,4]$, стосується залучення студентів до процесу оцінювання освітніх програм та інших процедур забезпечення їх якості.

Отримання періодичного зворотного зв'язку від здобувачів освіти - обов'язкова складова внутрішнього забезпечення якості освітніх програм. ЗВО має організовувати періодичні студентські опитування, результати яких повинні реально впливати на зміст навчання і викладання. Відсутність опитувань безпосередніх учасників освітнього процесу або суто формальний підхід до їх проведення є недоліком у контексті відповідності критерію 8 - внутрішне забезпечення якості ОП $[1,4]$.

Водночас опитування - не єдиний спосіб залучення студентів до процесів внутрішнього забезпечення якості. Так, у пункті 2 прописана вимога про обов'язкову участь органів студентського самоврядування у цих процесах. ЗВО має продемонструвати, що позиція органів студентського самоврядування стосовно будьяких питань організації освітнього процесу сприймається серйозно та $є$ важливим чинником для прийняття рішень.

Іншою позитивною практикою участі студентів у процесах забезпечення якості можна вважати проведення фокус-груп або залучення здобувачів освіти до груп забезпечення якості ОП (якщо існування таких передбачено внутрішньою системою забезпечення якості ЗВО).

Загальний зміст пункту 2 засвідчує, що студенти мають бути повноцінними партнерами в усіх процесах забезпечення якості ОП.

У Пораднику щодо заповнення відомостей самооцінювання ОП (для ЗВО) [3] ми нарахували 


\section{ДОСВІД ОРГАНІЗАЦЇ ТА ПРОВЕДЕННЯ ОПИТУВАННЯ СТУДЕНТІВ ПРО ЯКІСТЬ НАДАННЯ ОСВІТНІХПОСЛУГ В УНІВЕРСИТЕТІ}

30 позицій, які стосуються опитування здобувачів вищої освіти. Під час акредитації ОП за вимогою експертів 3ВО має надати (за потреби) документи та інші матеріали, які підтверджують факти залучення студентів до оцінювання ОП.

Анкетування здобувачів освіти доцільно проводити наприкінці навчального року (травеньчервень). Нормативними документами, у яких визначено основні засади організації опитування учасників освітнього процесу в університеті, $\epsilon$ “Заходи для забезпечення якості освітньої діяльності та якості вищої освіти”, "Положення про Центр забезпечення функціонування системи управління якістю освітньої діяльності", "Положення про забезпечення якості освітньої діяльності та якості вищої освіти”, “Положення про участь студентів у забезпеченні якості вищої освіти”, “Стандарти і рекомендації щодо забезпечення якості в Європейському просторі вищої освіти”. Процедура опитування студентів проводиться відповідно до наказу ректора університету "Про організацію і проведення опитування здобувачів вищої освіти”.

Інформаційний, методичний та програмний супровід відповідної процедури забезпечують три центри: Центр забезпечення функціонування системи управління якістю освітньої діяльності (ЦЗФСУЯОД), Інформаційно-обчислювальний центр і Центр дистанційного навчання. Це зумовлено, по-перше, масштабністю планованої роботи, по-друге, наміром провести опитування студентів у формі комп'ютерного анкетування, щоб забезпечити анонімність респондентів.

В опитуванні, яке проводилося в університеті в 2019 році, узяли участь здобувачі освітнього ступеня “Бакалавр" (усіх років навчання). Щоб надати можливість оцінити різні аспекти освітньої діяльності, студентам було запропоновано дві анкети: для початкових (I - II) курсів - “Якість надання освітніх послуг”, а для старшокурсників (III - IV курси) - “Якість самостійної роботи студентів".

Для студентів I - II курсів опитування було організоване з метою вивчення їхньої думки про якість надання освітніх послуг в УДПУ. Зокрема, здобувачі освіти мали можливість дати відповіді на 14 запропонованих запитань:

1. Чи задоволені Ви вибором спеціальності?

2. Чи знаєте Ви, що Ваше навчання відбувається відповідно до затвердженої освітньої програми?

3. Чи ознайомлені Ви з метою освітньої програми?

4. Оцініть, чи достатньо передбачено часу на вивчення навчальних дисциплін.
5. Оцініть, чи відповідає структура освітньої програми переліку навчальних дисциплін та Вашим очікуванням.

6. Які дисципліни, на Ваш погляд, є найменш цікавими для Вас? Чому?

7. Які дисципліни Ви хотіли б вивчати більш поглиблено?

8. Оцініть, будь ласка, якість освітніх послуг, які надає УДПУ імені Павла Тичини.

9. Чи доступні Вам підручники, методичні посібники, лекції тощо в електронній та друкованій формах?

10. Оцініть, наскільки задовольняє Вас якість підручників, методичних посібників, лекцій тощо в електронній та друкованій формах.

11. Чи задовольняють Ваші потреби комп'ютерне обладнання і програмне забезпечення освітнього процесу?

12. Чи задоволені Ви форматом консультацій, які проводять викладачі навчальних дисциплін?

13. Чи задоволені Ви роботою бібліотеки i читальних залів?

14. Чи задоволені Ви роботою системи Moodle?

Отже, анкета передбачала відповіді на запитання, чи знають студенти мету і зміст освітніх програм, як вони оцінюють відповідність структури освітньої програми переліку навчальних дисциплін та власним очікуванням, як характеризують рівень і якість забезпечення освітнього процесу матеріально-технічними та навчально-методичними ресурсами.

Варто зазначити, що відсутність цілісного уявлення студентів про особливості свого професійного розвитку, тобто незнання мети, якої вони повинні досягти разом зі своїми наставниками, провокує ситуацію демотивації у навчанні. У зв'язку з цим ЗВО необхідно спрямовувати свою роботу на системне формування у студентів початкових курсів усвідомленого розуміння мети їхнього професійного зростання.

Програмний комплекс до анкети розроблений працівниками Інформаційно-обчислювального центру і розміщений на веб-сайті університету за посиланням https://quality.udpu.edu.ua. Вхід до системи анкетування передбачав наявність персональних для кожного користувача логіна i пароля, що забезпечило анонімність учасників освітнього процесу та пришвидшило процедуру отримання узагальнених результатів опитування (рис. 1).

Здобувачі освіти завчасно були поінформовані про особливості комп'ютерного анкетування, але під час його проведення демонстрували 


\section{ДОСВІД ОРГАНІЗАЦЇ̈ ТА ПРОВЕДЕННЯ ОПИТУВАННЯ СТУДЕНТІВ}

ПРО ЯКІСТЬ НАДАННЯ ОСВІТНІХПОСЛУГ В УНІВЕРСИТЕТІ

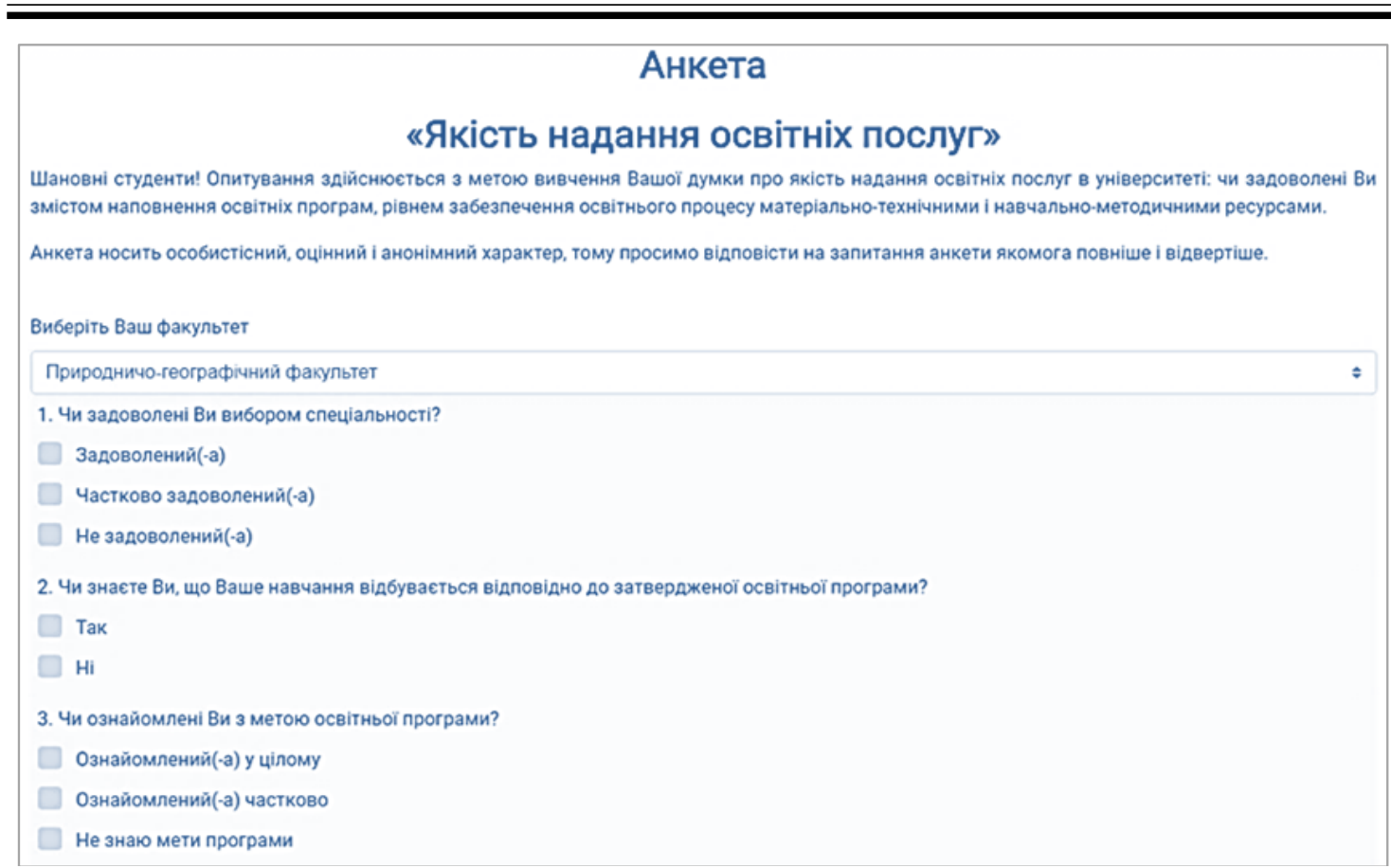

Рис. 1. Фрагмент анкети для студентів I - II курсів

посередню активність, незважаючи на забезпечення анонімності анкети. Як тільки такі опитування будуть звичними для студентів, вони виявлятимуть більшу активність у процесах забезпечення якості освіти та матимуть власне бажання заповнювати пропоновані анкети.

Узагальнені результати анкетування можна знайти на сайті університету за адресою https:// udpu.edu.ua/ (Про університет - Документи Документи 3 організації освітнього процесу Забезпечення якості освіти - Внутрішній аудит Анкетування студентів - 2018 - 2019 н.р. 1-2 курси).

Анкета “Якість самостійної роботи студентів”, запропонована для старшокурсників, спрямована на виявлення чинників, які стимулюють студентів до самостійної роботи; на 3'ясування труднощів під час виконання ними самостійних завдань; виявлення недоліків в організації самостійної роботи в структурних підрозділах університету тощо.

Анкета розміщена на сторінці університетського інформаційно-освітнього середовища (платформа Moodle) працівниками Центру дистанційного навчання, які і забезпечили доступ до анкети та технічну підтримку студентів. Вхід до системи персоніфікований, тобто кожен респондент під час анкетування був ідентифікований системою Moodle, що унеможливлювало проходження анкети сторонніми особами (рис. 2).

Студенти-старшокурсники були зорієнтовані на такі запитання:

\section{1. Що Вас стимулюе до виконання}

самостійної роботи? Мета запитання полягає в тому, щоб з'ясувати стимули та мотиви студентів до виконання ними самостійної роботи. Такими стимулами можуть бути: зв'язок результатів самостійної роботи з професійною діяльністю; врахування результатів виконання самостійної роботи у підсумковій оцінці; публічне схвалення, похвала, висока оцінка; вимогливість викладача. Відповіді на перше запитання (приклад результату відповідей на запитання можна переглянути на рис.3) допоможуть виявити та врахувати основні чинники, які стимулюють здобувачів до виконання самостійної роботи та удосконалити форми, методи і зміст завдань для такого виду робіт.

2. Що Вам найбільше подобається у виконанні самостійної роботи? Запитання спрямоване на визначення рівня сформованості у студентів мотивації до виконання самостійної роботи. Мотивами до такого виду роботи можуть бути: бажання поповнити і поглибити знання; перевірити свої знання; проявити самостійність; отримати високу оцінку; проявити творчість тощо. Аналіз відповідей респондентів забезпечить розуміння того, що $є$ запорукою успішного навчання здобувачів вищої освіти, допоможе виявити їхню зорієнтованість у процесі виконання завдань у межах самостійної роботи, зрозуміти, у якому напрямку розвивати мотиваційну сферу студентів, культуру їхньої самоосвітньої діяльності, активної суб'єктної позиції тощо.

3. Коли Ви отримуєте завдання для самостійної роботи? Це запитання допоможе 


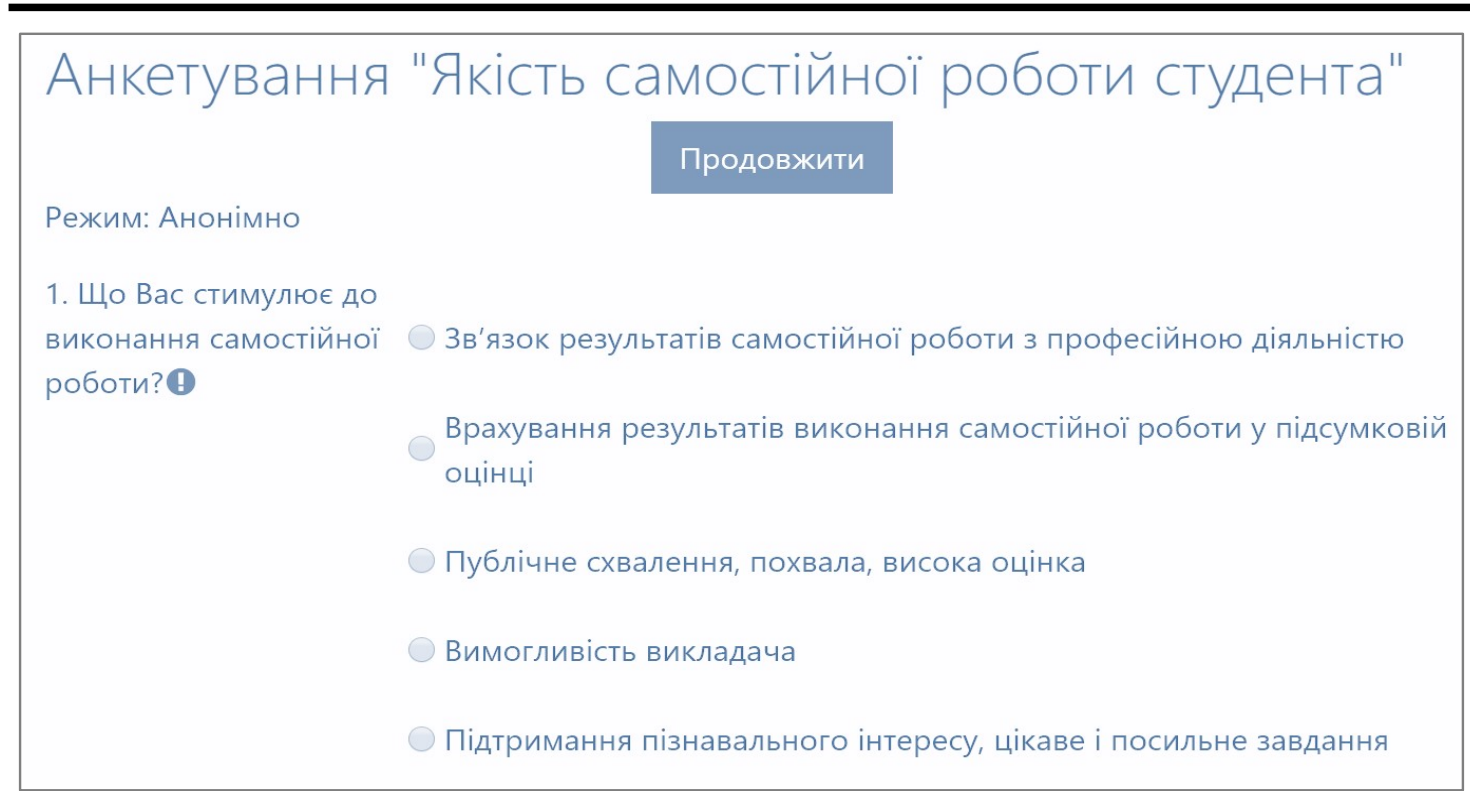

Рис. 2. Фрагмент анкети для студентів III - IV курсів

виявити певні тенденції в організації самостійної роботи здобувачів вищої освіти. Пропоновані варіанти відповідей (на початку семестру, протягом семестру, наприкінці семестру, ніколи) зорієнтовані на з'ясування частотності виконання студентами самостійних завдань.

4. Які труднощі у Вас виникають під час виконання самостійної роботи? Запитання передбачає чітке окреслення тих перешкод, із якими зіштовхуються здобувачі освіти під час виконання самостійної роботи. Зокрема, до них можуть бути зараховані: дефіцит часу на самостійну роботу; великий обсяг завдань; складність у відновленні інформації в пам'яті (особливо тієї, яка обтяжена термінами); відсутність чітких рекомендацій до виконання; невміння рівномірно розподіляти навантаження; складність у виділенні основного в матеріалі; невміння пов'язувати теоретичні знання 3 практикою; відсутність умінь працювати самостійно; потреба у допомозі викладача тощо.

5. Скільки Ви витрачаєте часу на день для самостійної підготовки до занять? Мета запитання - проаналізувати, який обсяг часу студенти витрачають на самостійну роботу протягом дня. Із цим запитанням тісно пов'язане наступне - шосте.

6. Як часто Ви виконуєте самостійні завдання протягом семестру? Щоб з'ясувати систематичність у виконанні самостійної роботи студентами, запропоновано такі варіанти відповідей: систематично, планомірно; час від часу; майже не виконую; виконую тільки під час сесії; виконую тільки ту роботу, якою захоплений (-а). Відповіді на аналізоване запитання засвідчать, чи усвідомлюють респонденти цінність і значимість пізнання, чи сформована у них потреба в систематичній самостійній роботі, у самоосвіті і самоактуалізації знань. Тому за варіантами відповідей на п'яте і шосте запитання 3ВО варто виробити план дій, спрямованих на формування в студентів стійкого інтересу до самоосвіти.

7. Чи звертастеся Ви за допомогою до викладачів, щоб виконати завдання для самостійної роботи? Відповіді респондентів на запитання дають змогу перевірити, чи відчувають студенти труднощі під час виконання самостійної роботи і чи потрібна їм допомога викладача.

8. Що Ви хотіли б мати під час виконання самостійної роботи? Щоб отримати інформацію про потреби студентів під час виконання самостійної роботи, у варіантах відповідей доцільно перерахувати все те, що може забезпечити якість виконання такої роботи, зокрема: план і рекомендації до виконання завдань; зразки виконання роботи; індивідуальна бесіда за результатами перевірки та аналізу самостійної роботи; інструктаж до роботи; можливості коригування роботи тощо. За результатами відповідей на аналізоване запитання науковопедагогічні працівники зможуть врахувати побажання студентів під час підготовки навчально-методичних матеріалів для самостійної роботи.

9. У якій формі викладачі здійснюють перевірку Вашої самостійної роботи? Запитання спрямоване на з'ясування того, яким 


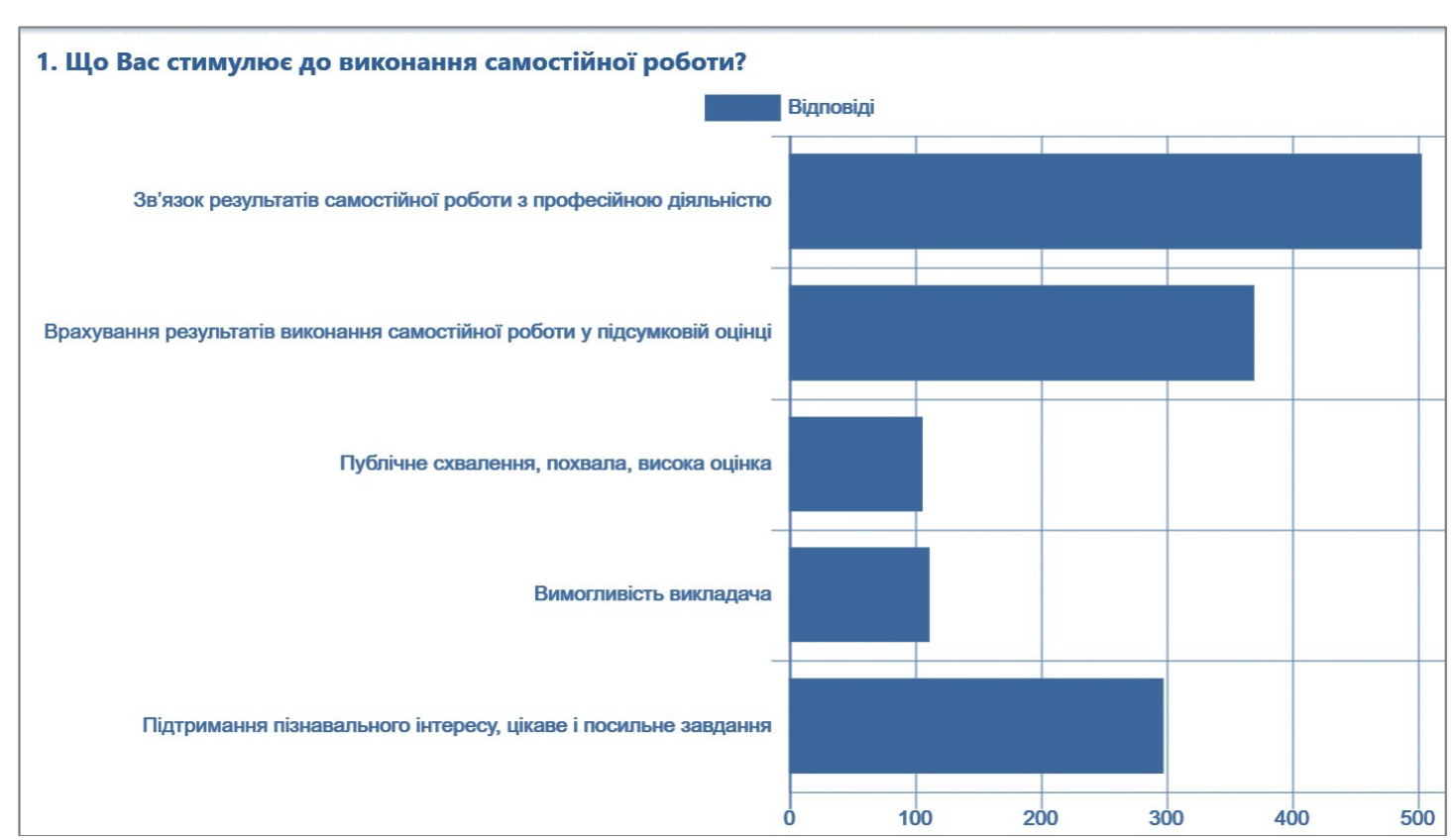

Рис. 3. Результати відповідей студентів III - IV курсів на запитання "Що Вас стимулює до виконання самостійної роботи?"

формам оцінювання самостійної роботи студентів надають перевагу наставники. У варіантах відповідей варто зазначити можливі форми перевірки, а саме: тестування; виконання індивідуальних завдань; співбесіда; колоквіуми; індивідуальні навчально-дослідні завдання; звіти до лабораторних та інших видів робіт; розрахунково-графічні та курсові роботи (проекти); публікації за результатами виконаної роботи.

10. Чи знасте Ви критерії оцінювання завдань для самостійної роботи? Від чіткого розуміння студентами критеріїв оцінювання самостійної роботи залежить якість їі виконання, незнання цих критеріїв або їх відсутність можуть призвести до демотивації у виконанні завдань. Науково-педагогічним працівникам варто дуже детально розробляти критерії оцінювання завдань за всіма видами самостійної роботи з навчальних дисциплін, інформувати студентів про ці критерії як на початку вивчення дисципліни, так і в процесі виконання завдань.

11. Яким ресурсам Ви надаєте перевагу під час виконання завдань для самостійної роботи? Запитання спрямоване на те, щоб виявити джерела отримання нових знань, яким надають перевагу студенти в самостійній роботі. Респондентам можна запропонувати у відповідях на запитання такий перелік джерел: бібліотека університету; інформаційно-освітнє середовище Moodle; мережа Інтернет тощо. Залежно від відповідей учасників освітнього процесу необхідно працювати над удосконаленням роботи тих

Молодь і ринок №1 (180), 2020 джерел, які безпосередньо належать університету. Наприклад, якщо незначна кількість студентів використовує Moodle як джерело отримання знань для виконання самостійних завдань, потрібно розробити заходи для якісної організації необхідних ресурсів в університетському інформаційно-освітньому середовищі.

12. Як часто Ви відвідуєте бібліотеку $i$ читальні зали університету? Частотність відвідувань студентами бібліотеки та читальних залів університету частково свідчитиме про рівень організації самостійної роботи студентів. Тому аналіз варіантів відповідей (1 - 2 рази на тиждень; $1-2$ рази на місяць; 1 - 2 рази в семестр; 1 - 2 рази на рік; не відвідую) допоможе виявити недоліки в роботі як науково-педагогічних працівників, так і здобувачів вищої освіти.

Узагальнені результати анкетування можна знайти на сайті університету за адресою https:// udpu.edu.ua/ (Про університет - Документи Документи з організації освітнього процесу Забезпечення якості освіти - Внутрішній аудит Анкетування студентів - 2018 - 2019 н.p._3-4 курси).

Висновок. Досвід проведення анкетування здобувачів вищої освіти є позитивною практикою у внутрішньому оцінюванні якості освіти. Залучення комп'ютерних технологій під час проведення опитувань значно спрощує процедуру отримання результату, оскільки така форма зручна не тільки для адміністрації, а й для студентів, які можуть дати відповіді в дистанційному режимі, iз мобільного телефону, у будь-якому місці, де $є$ 
мережа Інтернет. Практика організації такого анкетування свідчить про те, що оцінку освітніх послуг структурні підрозділи (факультети, кафедри) можуть проводити самостійно i організовувати періодичні опитування, анкетування студентів для отримання зворотного зв’язку від учасників освітнього процесу, з метою корекції освітніх програм спеціальностей, практик управління якістю і вдосконалення системи якості загалом.

\section{ЛІТЕРАТУРА}

1. Додаток до Положення про акредитацію освітніх програм, за якими здійснюється підготовка здобувачів вищої освіти (пункт 6 розділу I). URL: https://naqa.gov.ua/wp-content/ up loads / $2019 / 09 / \%$ D $0 \% 9$ A \% D $1 \% 80 \%$ D0\%B8\%D1\%82\%D0\%B5\%D1\%80\%D1\%96\%D1\%97.pdf (дата звернення: 11.11.2019).

2. Національна стратегія розвитку освіти в Україні на період до 2021 року. URL: http:// www.vnz.univ.kiev.ua/uploads/p_4_58429238.doc (дата звернення: 11.11.2019).

3. Порадник щодо заповнення відомостей самооцінювання освітньої програми (для закладів вищої освіти). URL: https://naqa.gov.ua/wp-content/ u p 1 o a d s / $2019 / 09 / \%$ d $0 \% 9$ f \%

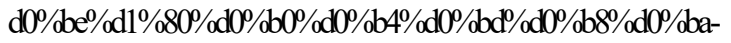
$\%$ d $0 \%$ b $4 \%$ d $0 \%$ o b b $\%$ d $1 \%$ $\% \mathrm{~d} 0 \% 97 \% \mathrm{~d} 0 \% 92 \% \mathrm{~d} 0 \% 9 \mathrm{e.pdf}$ (дата звернення: 11.11.2019).

4. Стеценко Н. М., Ткачук Г. В. Комп'ютерна підтримка процесу управління в загальноосвітніх навчальних закладах. Модернізація освітнього середовища: проблеми та перспективи: Матеріали Другої Міжнародної науково-практичної конференції, м. Умань, 5-6 жовтня 2017 року. Folia comeniana: Вісник Польсько-української науководослідницької лабораторії психодидактики імені Я. А. Коменського. Умань, 2017. с.202-204.

\section{REFERENCES}

1. Dodatok do Polozhennia pro akredytatsiiu osvitnikh prohram, za yakymy zdiisniuietsia pidhotovka zdobuvachiv vyshchoi osvity (punkt 6 rozdilu I) [Appendix to the Regulations on the accreditation of educational programs for the preparation of higher education applicants (Section I, paragraph 6)]. Available at: https:// naqa.gov.ua/wp-content/uploads/2019/09/ $\begin{array}{llllllllllllll}\% & \mathrm{D} & 0 & \% & 9 & \mathrm{~A} & \% & \mathrm{D} & 1 & \% & 8 & 0 & \% & \mathrm{D}\end{array}$ $0 \% \mathrm{~B} 8 \% \mathrm{D} 1 \% 82 \% \mathrm{D} 0 \% \mathrm{~B} 5 \% \mathrm{D} 1 \% 80 \% \mathrm{D} 1 \% 96 \% \mathrm{D} 1 \% 97$.pdf (accessed 11 Nov. 2019). [in Ukrainian].

2. Natsionalna stratehiia rozvytku osvity v Ukraini na period do 2021 roku [National Strategy for the Development of Education in Ukraine until 2021]. Available at: http://www.vnz.univ.kiev.ua/uploads/ p_4_58429238.doc (accessed 11 Nov. 2019). [in Ukrainian].

3. Poradnyk shchodo zapovnennia vidomostei samootsiniuvannia osvitnoi prohramy (dlia zakladiv vyshchoi osvity) [Educational Program Self Assessment Advisor (for Higher Education Institutions)]. Available at: https://naqa.gov.ua/wpc o n t e n t / u p l o a d s / $2019 / 09 /$

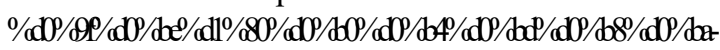

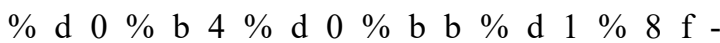
$\% \mathrm{~d} 0 \% 97 \% \mathrm{~d} 0 \% 92 \% \mathrm{~d} 0 \% 9 \mathrm{e} . p d f$ (accessed 11 Nov. 2019). [in Ukrainian].

4. Stetsenko, N. M. \& Tkachuk, H. V. (2017). Kompiuterna pidtrymka protsesu upravlinnia $\mathrm{v}$ zahalnoosvitnikh navchalnykh zakladakh [Computer support for management in general education institutions]. Upgrading the Educational Environment: Challenges and Prospects: Proceedings of the Second International Scientific and Practical Conference, Uman, October 5-6, 2017. Folia comeniana: Bulletin of the Polish-Ukrainian Scientific Research Laboratory of Ya. A. Komensky. Uman, pp.202-204. [in Ukrainian].

Стаття надійшла до редакції 27.11.2019

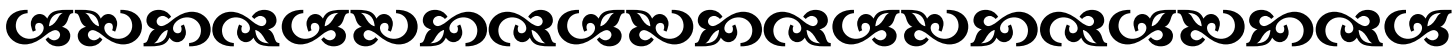

"Сила і можливості виховання невичерпні".

Василь Сухомлинсьжий

украйнський педагог

"Точніть робити те, що потрібно. Тотім робіть те, що можливо. I ви раптом виявите, цо робите неможливе".

Св. ФранцискАсізський італійський християнський святий

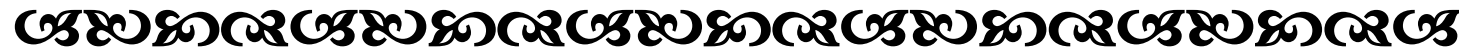

